\title{
Print Media Representations Of An UNuSUAL HeALTH EVENT: Chikungunya virus, risk and identity on Réunion island
}

\author{
Transforming Cultures eJournal, \\ Vol. 4 No 2 November 2009 \\ http://epress.lib.uts.edu.au/journals/TfC
}

\section{Philip Weinstein \& Srilata Ravi ${ }^{1}$}

\begin{abstract}
In 2005-6, the French Indian Ocean island of Réunion experienced a massive epidemic of the mosquito-borne viral infection Chikungunya. Reporting on the epidemic in the print media demonstrates a considerable lag compared to the realtime evolution of the epidemic, and this paper explores possible reasons for that delay. We analyse the content of print media articles about Chikungunya from two Reunionese newspapers (Témoignages and Clicanoo) and two newspapers from metropolitan France (Le Figaro and Le Monde). In the Reunionese newspapers, the delay in acknowledging the public health risk posed by the virus suggests passive denial in the early stages of the epidemic, followed by acceptance with blame attributed to the French metropolitan government - reflecting the uneasy historical relationship between the Reunionese and the government. In the French metropolitan newspapers, the delay is even greater and may reflect the influence of residual colonialist thinking on the priority placed on reporting on an epidemic in a remote tropical location: once a risk to metropolitan France is identified, reporting intensifies considerably. The media representations also highlight the importance of belief systems as modulators of people's risk perception and their subsequent health-protection behaviour. We suggest that a better understanding of these drivers of health behaviour in multicultural societies may provide important opportunities to reduce the community burden of disease. ${ }^{2}$
\end{abstract}

\footnotetext{
${ }^{1}$ Professor Philip Weinstein lectures in the School of Population Health at the University of Queensland and Professor Srilata Ravi lectures in the School of Humanities (European Language and Studies) at the University of Western Australia. Professor Weinstein's research interests are environmental health, medical geology, respiratory epedimiology, and vector-borne and waterborne diseases. Professor Ravi has published widely on Francophone literatures and cultures; migration, ethnicity and identity in Indian Ocean literatures and on travel literature. Her publications include Rainbow Colors-Literary Ethno-topographies of Mauritius (2007), Asia in Europe, Europe in Asia (2004, co-edited with Mario Rutten and Beng-Lan Goh) and L'Inde dans le genre romanesque français depuis 1947 (1997).

${ }^{2}$ We thank Dr Gilbert Potier, Mme Ségolène Bernard, Dr Karin LeRoux, Prof. Alain Michault and Mlle Bénédicte André for insightful discussions about the epidemic and for their hospitality whilst in Réunion. Lovisa Rosnäs assisted with the compilation of media reports, and Agnes Weinstein with typing the
} 
[Chikungunya, media, Réunion]

\section{Introduction}

In 2005-6, the Indian Ocean island of Réunion, a French overseas department since 1946, experienced a massive epidemic of the mosquito-borne viral infection Chikungunya - an "emerging infectious disease" never before seen in the Indian Ocean. ${ }^{3}$ More than 250,000 people, one third of the Island's population, were subject to a sudden onset of high fevers, rash, and debilitating joint pains, with several deaths - yet the public health authorities in metropolitan France were arguably slow to take the epidemic seriously. We have previously shown that discourses on tropicality and colonial distancing can help explain the slow reaction to the epidemic as represented in official public health bulletins from metropolitan France. ${ }^{4}$ We were also interested in comparing local representations of the epidemic with metropolitan ones, and therefore turned to newspaper articles about Chikungunya. Here we ask if residual colonialism and island identities influenced differences in print media representations of the risk posed by the virus, when comparing the content of articles about Chikungunya from two Reunionese newspapers (Témoignages and Clicanoo) and two newspapers from metropolitan France (Le Figaro and Le Monde). These newspapers were selected on the basis of representativeness of a broad crosssection of readership in both places: Témoignages has a distinctive Créole flavour (as evidenced for example by numerous interjections in the Créole language), and Clicanoo appeals to a broader Reunionese readership including French expatriates (Zoreilles); Le Figaro is widely acknowledged as having a right-wing agenda in metropolitan France and Le Monde is more broadly representative of public opinion, with its editorialists seen as "independent and committed intellectuals in the French tradition". ${ }^{5}$ Our study covers all articles in these

manuscript. The research was partially funded by the Graduate Research School at the University of Western Australia.

${ }^{3}$ An "emerging infectious disease" is defined as an infectious disease which is rapidly increasing in one or more of: the numbers of cases occurring, the geographical distribution of cases, or the severity of symptoms. Prominent examples include the recent pandemic of human HIV infections and the appearance of SARS.

${ }^{4}$ P. Weinstein \& S. Ravi (2008) “The failure of colonial 'distancing': changing representations of the 2005-6 Chikungunya virus epidemic in Réunion”, Singapore Journal of Tropical Geography 29: 221-35.

5 P. Moores (2006) "Media demonization, 'la fabrique de la haine' and Le Figaro", http://wjfms.ncl.ac.uk/MooresWJhtm, accessed 28/1/08; Le, E. (2004) "Active participation within written argumentation: metadiscourse and editorialist's authority", Journal of Pragmatics 36: 687. 
newspapers from their first mention of Chikungunya, to the end of the epidemic in November 2006. We interpret our findings with reference to discourses on island identities as well as theories of risk perception that relate to unusual health events.

\section{Historical and Cultural Context of the Media Representations}

La Réunion is a full (overseas) department of France, of which it has been an integral part with the same administrative status as a départment in metropolitan France since 1946. It does considerably better economically than the French average, with an economic growth rate of $4.9 \%$ compared to $1.2 \% .{ }^{6}$ Expectations are therefore that the minimum wage, social security payments, and availability of education and health care in Réunion match the standards set by metropolitan France. These expectations have partly been met: the minimum wage was brought to the same level as metropolitan France in 1996, but welfare payments are still 20\% lower; literacy is at $89 \%$ compared to $99 \%$ in France; and the infant mortality rate of 7.63/1000 is much lower than that of neighbouring Mauritius (14.59), but is still nearly double the rate in metropolitan France (4.21). ${ }^{7}$ Although much improved over the historical situation, these figures do suggest ongoing inequity - perhaps best illustrated by the unemployment rate, which at over $30 \%$ in Réunion remains more than three times the rate in metropolitan France, and the highest of any overseas department of France. ${ }^{8}$ The relationship between the Reunionese, the majority of whom are of mixed race, and their fellow French citizens in metropolitan France therefore might hide more persistent issues of discrimination and dependence than is at first obvious. As with many 'colonised' populations, discrimination against Créole Reunionese can persist either overtly or covertly, fuelled by the vicious cycle of lack of educational opportunity and socio-economic deprivation. To understand the evolution of this situation, it is important to appreciate the colonial history of the island, of which a short summary therefore follows.

\footnotetext{
${ }^{6} 2005$ data, INSEE (Institut National de la Statistique et des Études Économiques) (2006) Tableau économique de la Réunion, St-Denis, p.9.

${ }^{7}$ CIA (Central Intelligence Bureau) (2006) World Fact Book, http://sportsforum.ws/sd/factbook/index.html, accessed 4/6/06.

${ }^{8}$ INSEE 2006:125.
} 
When first discovered by Malay and Arab mariners in the Indian Ocean in the 15th century, Réunion was uninhabited, and they left it thus. The European discovery by the Portuguese captain Pedro de Mascarenhas in 1512 also did not lead to settlement, and it was over a century and a half before the first human inhabitants actually took up residence - a dozen Frenchmen of dubious reputation, living in a cave from 1663. Thus there were no inhabitants when the French settled, no resistance to settlement, and no dispossessed and oppressed indigenous population following 'colonisation'.9 African and Malagasy slaves, imported to support the growth of the coffee industry from 1715, certainly were oppressed, but not in any way that was different from the oppression of slaves elsewhere: they could, in fact, be considered to have been (relatively) fortunate to have benefited from the (relatively) benevolent rule of Mahé de la Bourdonnais, whose labour-saving management enabled many slaves to move away from hard labour and into artisanry. ${ }^{10}$ These slaves provided the basis of the island's Créole community, later to be joined by large numbers of indentured labourers for the island's sugar cane industry, chiefly from India and China, following the abolition of slavery in 1848. A brief period of economic prosperity ensued, with standards of living improving and the construction of roads and ports facilitating transport and communication. Later in the 19th century, the sugar crisis drove many small white landholders to retreat to the mountains to engage in small-scale subsistence farming, alongside freed slaves who had by then already adopted such a lifestyle. The resultant communities provided even greater opportunities for ethnic mixing than already existed on the island, thereby further effacing any historical 'racial' boundaries. This socioculturally and ethnically diverse population was then subject to successive crises - a series of serious epidemics including malaria and cholera, and the two World Wars during which the isolation of the island was felt acutely. Although living through these times together in many ways helped to unify the population and develop a Reunionese identity, departmentalisation in 1946 was not uniformly supported: the popularity of the island's pro-independence movement has fluctuated ever since, unfortunately epitomised by antigovernment demonstrations in 1991 in which 10 people died.

\footnotetext{
9 (“l'île vièrge”, D. Vaxelaire (2002) Portraits d'une île (Ste-Marie, Réunion: Azalées Éditions).)

${ }^{10}$ Y. Combeau \& E. Maestri (2002) Histoire de La Réunion, Paris: Nathan.
} 
With this historical background, and despite the lack of an indigenous population per se, the Créole community in Réunion has been and remains subject to the imposition of a dominant French culture in a situation analogous to that of colonial occupation. Discourses on colonialism therefore provide a useful framework within which to contextualise and examine representations of the Chikungunya epidemic in both Reunionese and metropolitan French newspapers.

\section{Representations in Reunionese Print Media: Témoignages and Clicanoo}

Newspapers both in Réunion and in metropolitan France were slow to pick up on the epidemic. There is no mention of Chikungunya in the Reunionese print media until April 2005, by which time the INVS had already recorded 24 cases for March, and over 300 to date; and there is no mention of the epidemic in the metropolitan French print media until January 2006, almost a year after the first cases. ${ }^{11}$ Media reporting therefore demonstrates a considerable lag compared to the real-time evolution of the epidemic (see Table 1).

In the Reunionese print media, the first articles to mention Chikungunya appear on 20/4/2005 in both newspapers, but only as a passing comment about the Chikungunya epidemic in the Comores. The Clicanoo article is much longer than its Témoignages counterpart, and is more detailed and more practical insofar as it offers advice on mosquito eradication and limiting the disease risk. This difference already sets the trend for the main divergence between the two newspapers, but they are similar in their reporting delays. The first article to report cases in Réunion appears in Témoignages on 2/5/2005 reporting 4 cases, and the second article appears two days later reporting 150 cases — on pages 6 and 9 respectively, almost as general interest articles on health rather than as news items reflecting the appearance of a new virus with dramatic increases in case numbers. In Clicanoo, the first article to report cases in Réunion does not appear until a week later $(11 / 5 / 2005)$, but articles are thereafter more frequent than in Témoignages; Table 1 shows the numbers of articles published by each newspaper in each month of the epidemic,

\footnotetext{
11 The INVS (Institut National de Veillance Sanitaire (National Institute of Health Surveillance) is the national coordinating body for communicable disease surveillance and control, and has responsibility for reporting on epidemics for all departments of France, including the overseas departments of La Réunion, Martinique, Guadaloupe and Guyane). All departments provide disease surveillance data to the INVS, where data are analysed centrally and the results published in INVS bulletins.
} 
highlighting this difference as well as showing the significant delay between the obvious increase in case numbers reported to the INVS and the priority given to print media reporting on the Chikungunya outbreak. These delays continue to be reflected in subsequent articles: the third and fourth articles in Témoignages appear 6 days later (20/5/2005 and 21/5/2005), and the fifth article a full 2 weeks later when case numbers have escalated to over 1000 cases. These articles are on pages 10, 6 and 8 respectively, still away from the front pages where apparently more newsworthy items are placed. The Clicanoo articles appear with greater frequency, rarely exceeding a week between articles, but also not showing any increase in frequency that might parallel the rapidly rising case numbers (See Table 1). The case numbers are readily available but a delay of many weeks is evident in their use - much longer than can be accounted for by the delays of several days normally associated with disease notification and preliminary epidemiological analysis: during this time, an astute journalist could easily have become aware of the risk posed by the epidemic and would have been well positioned to produce front page news on it.

Another aspect of these early reports is that they describe the epidemic in terms that appear to be the antithesis of sensationalism. The 14/5/2005 Témoignages article reports the disease as new ("touche pour la première fois l'océan Indien"), large ("épidémie de grand ampleur"), widespread ("présent dans tous les pays"), rapidly progressive (case numbers increasing as above), and serious ("symptômes graves") — enough to ring alarm bells with people with no public health training whatsoever. Yet these terms are used in a factual way, spread through the text in a way that dilutes them, and are moderated by reassurances about official action, a paucity of hospitalised cases, the fact that infected people are not contagious, and the usually non-fatal nature of the virus. Overall, the risk of the epidemic is very understated in these early reports; the short, late, and infrequent articles convey an impression of a mild disease which is preventable and being dealt with effectively by the authorities. Clicanoo, with a slightly more populist reporting style that includes many anecdotal personal statements, goes so far as to suggest that Chikungunya is so trendy that one might almost want to catch it ("C'est la maladie à la mode [...] qu'avec ce nom un brin exotique, on aurait presque envie de contracter la chikungunya", Clicanoo, 25/5/2005). The epidemic is presented as a trivial addition to the other 'tropical' mosquito-borne diseases, 
dengue and malaria, that are already familiar to the Réunionnese.$^{12}$ The Témoignage reports are dealing with the epidemic as a non-event, a minor public health incident that does not constitute a significant risk on an island that is perceived as modern with a solid public health infrastructure ("Une cellule de veille des services de l'État [DRASS] a été mise en place....", Témoignages 12/5/05. Clicanoo presents a clearer rôle for community involvement in combating the disease ("une lutte communautaire", Clicanoo 14/5/2005), but is no better in these early articles at conveying a sense of urgency.

There is no significant change in this delayed and downbeat reporting over the next few months; a full 6 weeks elapse between Témoignages articles 6 and 7 (15/6/2005 and $22 / 7 / 2005$ ) despite a corresponding jump in case numbers from 1,678 to 2,724 - and this during the southern winter/dry season when no vector-borne disease transmission would be expected (because of fewer mosquitoes). Témoignages articles 7 to 10 are very short, less than 200 words, but do add an invitation for new cases to contact the DRASS (Direction Regionale d'Affaires Sociales et Sanitaires) to help target mosquito control efforts. In the same period, Clicanoo publishes 23 articles specifically on Chikungunya, and also mentions the disease in other articles about, for example, football (which players are struck down, 18/6/2005) and teaching (what newly arriving teachers from France can expect, 23/8/2005). More so than Témoignages, but still without sensationalism, there are suggestions here that people are being affected in more than a trivial way. Then, in late September/early October 2005, there is a dramatic change in the nature of media representations - the articles finally acknowledge the existence of an 'unusual health event', and blame the government for it. For the first time, Clicanoo highlights the DRASS's failure to control the epidemic: the outbreak is now acknowledged to have never abated, despite the southern winter, and government incompetence is cited as the cause (“defaut d'organisation”, Clicanoo 12/9/2005). Later, but more vehemently, Témoignages follows suit on 13/10/2005 with an article that is suddenly much longer, more that 800 words, and highlights both the severity and potential for recrudescence of the epidemic with the onset of the southern summer. Articles become more frequent (in the order of days, then

\footnotetext{
${ }^{12}$ Malaria first appeared in Réunion in 1869, was declared eradicated in 1973, and now only imported cases continue to occur. Dengue first appeared in 1873, and although also at one stage eradicated (1952), introduced cases seeded further epidemics in 1977-78 and 2004, as well as concurrently with the 2005-6 Chikungunya epidemic.
} 
moving to sometimes two articles per day), and fundamentally different in content. During the 2 months' interval between the $10^{\text {th }}$ Témoignages article and the $11^{\text {th }}$, the existence of an 'unusual health event' has finally been accepted: it is reported that the southern winter has not interrupted transmission, that there have now been over 4,000 notified cases, that serious complications have arisen, including foetal infections and meningitis and, importantly, that a whole-of-community approach is necessary to combat the epidemic ("L'État seul ne pourra pas éradiquer le virus"; Témoignages 13/10/2005). The weight of evidence has made it impossible to deny the severity of the epidemic any longer.

Accepting that the epidemic was worse than thought and that a recrudescence in the oncoming summer would seem inevitable, articles now firmly blame the government for failing to control the situation. The issue is quickly politicised, and questions are asked in both newspapers about the adequacy of the evaluation of the epidemic, the appropriateness of the public health response, and the apparent tendency of the government to avoid blame by transferring the responsibility for controlling the epidemic to families and local communities. ${ }^{13}$ Although individual and community involvement in source reduction (removal of potential breeding sites) is essential in urban mosquito-borne disease control, the spraying of insecticides at a broad scale by competent operators is obviously beyond the capability of local communities (“...n'est pas possible [..] aux agents d'une commune d'appliquer un tel traitement", Témoignages 14/110/05). In an angry letter signed by 32 local general medical practitioners and reproduced in Témoignages 18/1/06, a major point is made of the inappropriateness of blaming the Reunionese for allowing the virus to spread, when mosquito control at a departmental scale needs to led by the government. More generally the government is accused of failing to protect the health of the public ("Les services de l'État ont failli à leur mission de protection de la santé publique", Témoignages 14/10/2005), despite having had a warning from the World Health Organization several years earlier that the virus was serious enough to be considered as a

\footnotetext{
13 In urban environments, vector-borne disease control depends on top-down and bottom-up management approaches working synergistically. Ultimately only individual householders can eliminate all the containers of standing water that might provide suitable environments for mosquito larvae (garbage, pot plants, blocked gutters, old tyres, etc.); but only governments can coordinate the large-scale spraying of insecticides required to kill larvae in larger water bodies, or to 'knock-down' adult mosquitoes during an epidemic.
} 
potential agent of bioterrorism. ${ }^{14}$ This latter argument finally demonstrates the type of sensationalism one might have expected when faced with an 'unusual health event', and the emotive term "bioterrorism" now appears in the title of an article promoted to page 3 ("Le bioterrorisme peut utiliser le chikungunya", Témoignages 17/10/2005). A barrage of interventions that could have or should have been implemented are identified in subsequent articles: why was WHO assistance not requested from the beginning, as it was in Comores during the same outbreak? Why is there no attempt to devise a specific treatment or antidote? Why is the disease burden underestimated and trivialised when an equivalent problem in metropolitan France would have precipitated a massive response? For each of these questions, the responsibilities and failures are projected onto the (French Metropolitan) government, allowing the island and its inhabitants to assume the role of victims.

In the subsequent months, new themes are introduced and additional issues raised in relation to the epidemic, including control campaigns, loss of tourism income, and environmental concern about insecticides; but the undercurrent of public outrage remains consistently represented and firmly anti-government — if control campaigns are unsuccessful, if tourist income is lost, and if local ecosystems are poisoned, these effects remain squarely a result of governmental mismanagement. Insofar as these media representations are likely to reflect public opinion, their consistency illustrates the fact that perceived health risks and the trust of public health organizations are mental constructs that are very difficult to shift once formed. ${ }^{15}$ One does, however, have to admire the creativity of the Reunionese, examples of which include blaming al- Qaida (Clicanoo, 14/2/06) and issuing an album of Séga, the local dance music, with a Chikungunya theme (Clicanoo, 15/6/06); but the shift from passive denial to acceptance with active government

\footnotetext{
${ }^{14}$ WHO (World Health Organization) (2002) Se préparer pour faire face à l'usage délibéré d'agents biologiques: Pour une approche rationelle face à l'impensable, Geneva: World Health Organization. This WHO report summarises the requirements for minimising the potential impact of microbial pathogens used as agents of bioterrorism. It lists the agents of potential concern (which include Chikungunya virus), and outlines global surveillance and response needs to limit the spread of epidemics. The recommended strengthening of surveillance systems would equally improve countries' ability to respond effectively to "emerging infectious diseases".

${ }^{15}$ M. L. Finucane (2004) "The psychology of risk judgements and decisions", in N. Cromar, S. Cameron \& H. Fallowfield (eds) Environmental Health, South Melbourne: Oxford University Press.
} 
denunciation is the only significant transition in representation evident in Témoignages and Clicanoo up to the end of the epidemic in November 2006.

\section{Representations in French Metropolitan Print Media:}

\section{Le Figaro and Le Monde}

The first mention of Chikungunya in the metropolitan print media studied is in Le Monde on 16/12/2005: a technically detailed and politically neutral article reports on the disease and its presence in Réunion, including the control efforts being implemented. The article is an outlier insofar as the next mention does not occur for another 5 weeks, but the fact that this information is available and has appeared without being followed up is an indication of the low priority placed on reporting on such a 'tropical' health issue - at least until a 'mediagenic' controversy is later identified. In Le Figaro (21/1/2006) the first article appears almost a full year after the first cases were registered by the INVS; and it is not so much about the epidemic per se, but about the conflict ("polémique") between the island's general medical practitioners and the government public health services. In a letter by local general practitioners, the government is accused of underestimating the extent of the epidemic, of not taking appropriate action, and of inappropriately blaming the islanders for allowing the virus to spread (see also above, Témoignages 18/1/06). This attack on the French metropolitan government health services and representatives remains the theme for the next four articles in Le Figaro: case numbers are presented in support of the general practitioners' claim, but official rebuttals are also documented and include statements of the massive commitment of personnel to mosquito control (Figaro 28/1/2006), the implementation of a surveillance system by the INVS (Figaro 30/1/2006), and official confirmation that the situation is under control ("Le probleme est réglé", Figaro $30 / 1 / 2006)$.

Le Monde is initially less focused on this controversy and again provides articles that appear to be richer in factual detail, explaining the need for mosquito control and the appearance of severe complications not previously recorded (29/1/2006, 4/2/2006). However, a very metro-centric interest is apparent even from the early articles: the emphasis is on the metropolitan public health officials' thoughts on the epidemics, the 
metropolitan mosquito controllers being sent to Réunion, and the economic consequences for the tourism industry. The Director General of Health is quoted as explaining that the unusual circumstances arise because a developing world epidemic has established itself in the developed world (“...une épidémie de pays en voie de développement qui survivent [sic] dans un pays dévelopé", Le Monde 4/2/2006). The controversy is picked up more on $8 / 2 / 2006$, highlighting the rapid spread of the epidemic despite the large number of government driven interventions. Le Figaro has in the interim picked up on the inundation of the island's hospitals reaching crisis point ("tous les hôpitaux de l'île [vivent] en état de crise", Le Figaro 6/2/2006), with the theme of controversy still remaining dominant: the Reunionese are reported as feeling abandoned and panicked despite many personnel, much financial support, and free anti-mosquito kits being provided by the government. The statement "They had forgotten that they were an Indian Ocean island" ("La Réunion a oublié qu'elle était une île de l' océan Indian", Le Figaro 6/2/2006) indicates that the islanders should not be so surprised by an epidemic of tropical disease since their island is, after all, in the tropics.

In Le Figaro, the epidemic per se (disease burden, spread) only becomes the dominant theme when it is realised that the vector mosquito, Aedes albopictus, also occurs in metropolitan France - and that an importation risk for Chikungunya may therefore exist (Le Figaro 9/2/2006, 25/2/2006). From this point on, the polemical differences of opinion between islanders and officials take a back seat, and information about the epidemic is presented in three major areas that are presumably of direct interest to the metropolitan readership, now increasingly aware of the threat to metropolitan France: the seriousness of the disease once contracted, the latest research findings, and the appropriateness of the public health response. Severity of infection: although originally thought to be benign, the severe complications that can arise are now highlighted (Le Figaro 18/2/2006), particularly neonatal meningoencephalitis (Le Figaro 27/2/2006), and Chikungunya-associated mortality which has never before been recorded ("Premier décès attribué au chikungunya", Figaro 6/3/2006). The seriousness of the disease becomes a major tourist deterrent (Figaro 23/2/2006, 1/3/2006). Research findings: knowledge generation about the 'tropical disease' becomes a priority, and is coordinated by a newly formed national research centre with over 9 million euros of funding (Le Figaro 22/2/2006, 27/2/2006). The aim is to establish 
why severe symptoms never before recorded have appeared in this epidemic. A major launch of research on the island is highlighted at the end of February (Le Figaro 28/2/2006). Appropriateness of response: the official management of the epidemic is now described as possibly negligent (Le Figaro 22/2/2006) bordering on a total stuff-up ("gabegie totale", Le Figaro 23/2/2006), and emphasising that virtually nothing was done in terms of health promotion (community education about control and avoidance measures). Some 76 million euros are invested to provide free medication and repellents to the needy, to step up mosquito control, to fund research, and to revitalise the devastated tourist industry (Le Figaro 27/2/2006).

No similar change is reflected in Le Monde, where the importation risk is not highlighted and the emphasis continues to remain on other metropolitan issues - the travels to the island of the President and Ministers (24/2/2006 and following), and the arrangements for tourists to rebook their flights for later travel without penalty $(16 / 2 / 2006)$. The islanders are nevertheless afforded an intermittent voice, and here too the feeling of abandonment comes through strongly - particularly when the attention paid to their epidemic is compared to the far greater interest shown in bird flu ("Les poulets sont plus importants que les Réunionnais", Le Monde 22/2/2006). ${ }^{16}$

From March 2006, a significant decrease in the number of cases is reported ("épidémie en repli", Le Monde 14/3/06; "décru spectaculaire"; Le Figaro 30/3/2006), and subsequent articles on the Réunion epidemic are limited to reporting on this continuing downward trend in both numbers of cases and in impact. Some selected research findings are discussed intermittently, and there is then an ever-decreasing interest shown (which reflects in both the number and content of articles), until the end of the epidemic and study period in November 2006.

\footnotetext{
${ }^{16}$ Although 'Bird Flu' virus is closely related to human influenza virus and can infect people, without a significant mutation it cannot be transmitted from person to person. Because Bird Flu was and (at the time of writing) remains epizootic (epidemic in animals) on a global scale, and because the possibility of mutation to cause a human flu pandemic remains, there is a global 'hysteria' to prepare for the worst. It is understandable that a population experiencing an actual epidemic of Chikungunya should be cynical about the disproportionate amount of time, energy and funding being spent on a potential epidemic of flu.
} 


\section{Discussion}

A key finding in analysing these media reports is the significant delay in reporting on the epidemic: firstly in the Réunionnnais newspapers, suggesting passive denial in the early stages of the epidemic; and secondly, in the French metropolitan newspapers, suggesting that residual colonialist thinking may be influencing the priority placed on reporting on such an epidemic in a remote tropical location. It is possible that a contributing factor to the delays is also a failure of public health officials to adequately communicate the potential gravity of the situation to the media and public; Watin highlights the apparent lack of interest of public health authorities in the early stages of the epidemic, ${ }^{17}$ and we have previously shown that the rhetoric of the official INVS bulletins on the epidemic reflected an underestimate of the potential public health risk posed by Chikungunya. ${ }^{18}$ However, regular INVS bulletins giving case numbers were readily available to journalists from the first month of the epidemic (see Table 1.), so we argue here that the delays were more likely to result from a low publication priority for reporting on the epidemic for either or both of the above reasons: early denial and postcolonialist trivialisation of the public health risk posed by the virus.

The manner in which public health risk is constructed is a result of risk perception - a social construct in which health hazards are mentally 'scaled' from negligible to catastrophic based on characteristics of the hazard itself as well as on attributes of individuals in the population of interest. To better understand such 'scaling', the relevant characteristics of hazards have been construed in terms of 'personalities' defined predominantly by "dread risk" and "unknown risk". ${ }^{19}$ Dread risk is the extent to which the hazard is dreaded by the community, with strong elements of lack of control, being involuntary, inequitable, and potentially fatal or catastrophic: for example, nuclear reactor accidents are perceived as posing a greater risk to health than does smoking. Unknown risk

\footnotetext{
${ }^{17}$ M. Watin M (in press) «Polémique, rumeur et tension: Aspects de la « crise » du chikungunya dans l'espace publique médiatique réunionnais », in Chronique d'une crise sanitaire, économique et sociale: L'île de La Réunion face au Chikungunya, Paris: UMR Prodig, Infogéo.

${ }^{18}$ Weinstein and Ravi 2008.

${ }^{19}$ P. Slovic, T. Malmfors, C.K. Mertz, N. Neil \& I.F.H. Purchase (1997) "Evaluating chemical risks: results of a survey of the British Toxicology Society", Human and Experimental Toxicology 16: 289-304; P. Slovic (1998) “The risk game”, Reliability Engineering and Systems Safety 59: 73-7; Finucane 2004.
} 
is the extent to which the risk is unfamiliar to the community, with strong elements of unobservability, lack of understanding, and delayed consequences: for example, pesticides and asbestos are perceived as posing a greater risk to health than do car accidents. The 'personality' of a hazard is the mix of dread risk and unknown risk that it presents, and at the media and community level is obviously strongly influenced by the perceivers' particular mix of age, gender, ethnicity, education, sociopolitical attitudes, and belief systems (including religion). In the specific case of the Réunion Chikungunya epidemic, different Reunionese with different backgrounds and experience therefore perceived the risk of mosquito-borne diseases differently: for example, residents of European origin were very concerned about being bitten by these (unknown, tropical) insects, as reflected in the media by their complaints about the inadequacy of mosquito control efforts. Their feelings of lack of control were exacerbated by feelings of abandonment (inequity), leading to heightened perceptions of "dread" risk. The non-white Créole community, on the other hand, perceive the (known, local) mosquitoes only as a nuisance, against which herbal repellents provide adequate protection (Le Monde, 23/2/06); they thus have control and, in any case, often do not believe that mosquitoes cause the disease.

In the metropolitan newspapers, the perception of the severity of the public health risk posed by the disease, and the need to understand (research) and control it, take on new significance after the realisation that the epidemic could pose a threat to residents of metropolitan France (Le Figaro 9/2/2206, and "Plus proche que l'on ne croit", 25/2/2006). While the disease was seen as a purely tropical phenomenon, the central government could afford to relax ("Le fait qu'il s'agisse d'un départment d'outre-mer a sans doute conduit le pouvoir central à une certaine négligence", Figaro 22/2/2006). With the possible threat to metropolitan France identified, the rhetoric of the newspaper articles changes to one of a more inclusive approach to 'health for all', with suggestions such as the modification of national surveillance systems to better deal with emerging infectious diseases (Le Figaro, 2/2/2006). ${ }^{20}$ There is a realisation that to decrease the public health risk to their own populations, Western countries need to invest in protecting the health of more vulnerable populations in developing and tropical countries that can act as sources of emerging

\footnotetext{
${ }^{20}$ See note 20 , above.
} 
infectious diseases (Le Figaro, 3/3/2006). Such an approach is consistent with recent developments in international public health policy, and where better for France to start reducing this international risk of emerging infectious diseases than in one of its own overseas departments? ${ }^{21}$

There are representations in the French metropolitan print media that clearly indicate a persistence of colonialist thinking in officialdom. Two examples have been cited: the explanation of a third world disease impinging on the developed world, and the lack of surprise that might have been anticipated when a tropical disease occurred on a tropical island (above; Le Monde, 4/2/2006; Le Figaro 6/2/2006). The emphasis on research provides another such example: although not apparent until more than a year after the onset of the epidemic, the new research emphasis can be interpreted as a scholarisation of the problem. An academic approach to knowledge generation allows metropolitan public health officials and politicians to distance themselves from the very real suffering, including deaths, to which over 250,000 people - one third of the island's population - were subject. This process of officialdom distancing itself from the epidemic is similar to one evident in the INVS reports on Chikungunya, which represent the epidemic in tropicalist terms with a degree of unempathetic 'othering' of Indian Ocean health events. ${ }^{22}$ The effects of these colonialist representations are to contribute both directly and indirectly to the perceived risk posed by Chikungunya: directly because they allow officialdom to distance itself from the risk by 'othering' the disease to the remote tropics, and therefore perceiving no risk to metropolitan France; and indirectly because such representations influence the formation of risk perceptions by the (metropolitan) readership.

The Reunionese newspapers, by contrast, contain few representations of the nature of the risk, but focus strongly on the attribution of blame for the risk. After an initial period of apparent denial of the presence of a potential public health hazard, the presence of such a hazard is accepted and blamed firmly on the government. Poumadère describes this

\footnotetext{
${ }^{21}$ WHO (World Health Organization) (2000) Consensus meeting on surveillance of infectious diseases: Report on a WHO meeting, Grottaferrata, Italy 4-7 April 2000, Regional Office for Europe: World Health Organization.

${ }^{22}$ For detailed discussion, see Weinstein and Ravi 2008.
} 
transition as reflecting the change from social attenuation to social amplification of the constructed risk (passage de l'atténuation à l'amplification sociales de ce risque) ${ }^{23}$ and there is also the possibility of an element of reciprocity here insofar as the media itself may have influenced the public perceptions of risk posed by the epidemic. ${ }^{24}$ From a certain perspective, this dichotomous representation of the epidemic - with passive denial on one hand and acceptance with active government denunciation on the other - reflect the dichotomous aspects of Reunionese identity. Denial "haunts the contemporary Reunionese discourse", with a violent history of slavery, indentured labour and colonialism still not being adequately acknowledged. ${ }^{25}$ In such an historical environment, Glissant interprets passive denial as a cultural trait that results from that environment itself; only physically strong but passive slaves survived. ${ }^{26}$ And there was suffering. Suffering "turns into lament, lament into anger, anger into violence [...] against France", providing an undercurrent that persists through two centuries of slavery and one century of colonialism right up to the present day. ${ }^{27}$ Thus, once the scale and extent of suffering from Chikungunya infection became undeniable, the suffering turned to anger against the 'French' government, with representations in the media reflecting this by means of fervent denunciations. "Que font les élus?" (What are the elected representatives doing?) is often heard in relation to any discontent on Réunion, and in a sense is 'othering' the problems of the island onto metropolitan France. ${ }^{28}$ This is a direct reversal of the metropolitan 'othering' of tropical diseases that is evident as 'distancing' (discussed above), and can be interpreted as a form of "writing back". ${ }^{29}$

${ }^{23}$ B. Poumadère (2007) «Le Chikungunya à la Réunion: entre atténuation et amplification sociales du risque » in Abstracts, Chikungunya et autres arboviroses émergentes en milieu tropical (CRVOI and INVS, 3-4 December 2007, Saint-Pierre, La Réunion): 340.

${ }^{24}$ B. Idelson (2007) «L'épidémie de Chikungunya à la Réunion, medias, opinion publique et pouvoirs publiques dans la crise" in Abstracts, Chikungunya et autres arboviroses émergentes en milieu tropical (CRVOI and INVS, 3-4 December 2007, Saint-Pierre, La Réunion): 339.

${ }^{25}$ F. Vergès (2003) "The Island of Wandering Souls" in R. Edmond \& V. Smith (eds.) Islands in History and Representation, London: Routlege Research in Postcolonial Literatures, p.162.

${ }^{26}$ E. Glissant (1981) Le Discours antillais, Paris: Seuil, p.101.

${ }^{27}$ Vergès 2003: 162.

${ }^{28}$ Vergès 2003: 165.

${ }^{29}$ B. Ashcroft, G. Griffiths \& H. Tiffin (1989) The Empire Writes Back: Theory and Practice on PostColonial Literatures, London: Routledge. 
An interesting debate is that surrounding the extent and appropriateness of involvement of Reunionese in mosquito control to combat the epidemic. Complaints about the lack of health promotion activities and community involvement have been presented above (Le Figaro, 23/2/2006), and are reinforced by descriptions of hundreds of mosquito controllers being deployed from metropolitan France, rather than enlisting local Reunionese (Le Monde, 22/2/2006). However, it could be argued that placing more emphasis on enlisting locals in mosquito control operations could have jeopardised such operations: a full two thirds of Reunionese do not believe that the disease is mosquito-borne, and are therefore unlikely to have embraced the campaign efficiently and effectively. ${ }^{30}$ Some insight into the local belief systems that result in this situation is provided in the form of a report about a lady who has used citronella (a herbal mosquito repellent) for the last 40 years, and has always been all right so does not believe that the ill could originate from the insects (Le Monde, 23/2/2007). Such a belief is reinforced by the observation that the mosquitoes are being killed, but that the epidemic is worsening. A hospital psychologist explains that in times of crisis old beliefs and superstitions resurface (Le Monde, 23/2/2007), and Réunion is well known for a preponderance of such beliefs. ${ }^{31}$ Thus an exploration of local belief systems would appear integral, even critical, to managing an 'unusual health event' in the multicultural environment of Réunion, particularly with respect to informing health education and public health practice about what approaches might be most culturally appropriate on the island.

Belief systems are fundamental modulators of people's risk perception and their subsequent health protective behaviour, ${ }^{32}$ yet consideration of these cultural aspects may have been overlooked in the top-down management of the Chikungunya epidemic by the French metropolitan government. Religion, in particular, stands out as a determinant of perceived

${ }^{30}$ B-A, Gaüzère and P. Aubry (2006) Le chik, le choc, le cheque, Sainte-Marie (Réunion): Azalées Éditions, p. 25.

${ }^{31}$ As a result of the varied ethnic makeup of the Reunionese, a great variety of belief systems coexist and mingle on the island, ranging from animist magic of Malagasy origin, through Hindu, Buddhist and Islamic beliefs, to Roman Catholicism. An example of the interesting interactions between these religions is afforded by the grave of the late $19^{\text {th }}$ century sorcerer and bandit Le Sitarane in St-Pierre: black magic rites are practiced at his grave in a Catholic cemetery - the latter incidentally also providing a variety of water holding containers for both flowers and mosquito larvae.

${ }^{32}$ M. Douglas \& A. Wildavsky (1982) Risk and culture: An essay on the selection of technical and environmental dangers, Berkley: University of California Press. 
risk, and forms the subject of another discussion which is beyond the scope of the present paper. Perceptions of risk are rapidly formed and difficult to alter, making it imperative to explore the potential influence of different belief systems before an understanding of them becomes critical to the management of an 'unusual health event'. Armed with this knowledge, public health practitioners could have a more powerful opportunity to reduce the community burden of disease, because they are then in a position of influencing the early formation of different community perceptions of risk, and thus also the translation of those perceived risks into public health practice. We have shown here that such an approach could be particularly valuable in a multicultural society where community perceptions of risk may be different from those predicted in a Western paradigm. 


\section{Table 1}

The number of cases of Chikungunya by month and the corresponding numbers of print media reports mentioning Chikungunya. A considerable delay is evident between the first occurrence of cases and the first articles in the Reunionese newspapers Témoignages and Clicanoo; a further delay is evident before the appearance of articles in the metropolitan French newspapers Le Figaro and Le Monde.

\begin{tabular}{|l|r|r|r|r|r|}
\hline Month & Number & \multicolumn{3}{|c|}{ Number of articles } \\
\cline { 3 - 6 } & of cases* $^{*}$ & Témoig. & Clicanoo $^{+}$ & Le Figaro $_{\mid}$ & Le Monde \\
\hline February 05 & 0 & 0 & 0 & 0 & 0 \\
March & 24 & 0 & 0 & 0 & 0 \\
April & 281 & 1 & 1 & 0 & 0 \\
May & 1486 & 4 & 10 & 0 & 0 \\
June & 1234 & 2 & 9 & 0 & 0 \\
July & 449 & 1 & 3 & 0 & 0 \\
August & 410 & 3 & 5 & 0 & 0 \\
Sept & 458 & 0 & 7 & 0 & 0 \\
Oct & 616 & 11 & 15 & 0 & 0 \\
Nov & 967 & 9 & 24 & 0 & 0 \\
Dec & 6667 & 20 & 19 & 0 & 1 \\
January 06 & 54136 & 77 & 146 & 6 & 2 \\
Feb & 127073 & 169 & 482 & 41 & 34 \\
March & 45202 & 70 & 319 & 29 & 13 \\
April & 14667 & 31 & 116 & 11 & 7 \\
May & 5267 & 20 & 91 & 10 & 11 \\
June & 2700 & 17 & 65 & 1 & 2 \\
July & 141 & 20 & 48 & 2 & 1 \\
August & 90 & 12 & 45 & 3 & 1 \\
Sept & 57 & 10 & 67 & 6 & 1 \\
Oct & 57 & 9 & 56 & 4 & 3 \\
Nov & 32 & 6 & 40 & 2 & 2 \\
\hline
\end{tabular}

\section{Based both on notifications (before Dec 05 and after June 06) and estimates (Dec 05 to June 06 inclusive) from the INVS (2005-6).}

\footnotetext{
${ }^{+}$Includes letters to the Editor.
} 


\section{Bibliography}

Ashcroft, B., Griffiths, G. \& Tiffin, H. (1989) The Empire Writes Back: Theory and Practice on Post-Colonial Literatures, London: Routledge.

CIA (Central Intelligence Bureau) (2006) World Fact Book, http://sportsforum.ws/sd/factbook/index.html. Accessed 4/6/06.

Clicanoo (2005-06) All articles containing the search term "Chikungunya", 2005 and 2006 http://www.clicanoo.com/, accessed November 2006.

Combeau, Y. \& Maestri, E. (2002) Histoire de La Réunion, Paris: Nathan.

Douglas, M. \& Wildavsky, A. (1982) Risk and culture: An essay on the selection of technical and environmental dangers, Berkley: University of California Press.

Finucane, M. L. (2004) "The psychology of risk judgements and decisions" in N. Cromar, S. Cameron \& H. Fallowfield (eds.) Environmental Health, South Melbourne: Oxford University Press.

Gaüzère, B-A. \& Aubry, P. (2006) Le chik, le choc, le cheque. Sainte-Marie (Réunion): Azalées Éditions.

Glissant, E. (1981) Le Discours antillais, Paris: Seuil.

Idelson, B. (2007) «L'épidémie de Chikungunya à la Réunion, medias, opinion publique et pouvoirs publiques dans la crise », in Abstracts, Chikungunya et autres arboviroses émergentes en milieu tropical (CRVOI and INVS, 3-4 December 2007, Saint-Pierre, La Réunion).

INSEE (Institut National de la Statistique et des Études Économiques) (2006) Tableau économique de la Réunion, St-Denis: INSEE.

INVS (2005-6) « Points epidémiologiques hebdomedaires sur l'épidémie de chikungunya à La Réunion », http://www.invs.sante.fr/surveillance/chikungunya/actu.htm. Accessed 10/12/06.

Le, E. (2004) "Active participation within written argumentation: metadiscourse and editorialist's authority", Journal of Pragmatics 36: 687-714.

Le Figaro (2005-06) All articles containing the search term "Chikungunya", 2005 and 2006, http://www.lefigaro.fr/, accessed November 2006.

Le Monde (2005-06) All articles containing the search term "Chikungunya", 2005 and 2006. http://www.lemonde.fr/, accessed November 2006.

Moores. P. (2006) «Media demonisation, 'la fabrique de la haine' and Le Figaro », http://wjfms.ncl.ac.uk/MooresWJ.htm, accessed 28/1/08.

Poumadère, B. (2007) «Le Chikungunya à la Réunion: entre atténuation et amplification sociales du risque ", in Abstracts, Chikungunya et autres arboviroses émergentes en milieu tropical (CRVOI and INVS, 3-4 December 2007, Saint-Pierre, La Réunion).

Slovic, P., Malmfors, T., Mertz, C.K., Neil, N. and Purchase, I.F.H. (1997) "Evaluating chemical risks: Results of a survey of the British Toxicology Society", Human and Experimental Toxicology 16: 289-304.

Slovic, P. (1998) “The risk game”, Reliability Engineering and Systems Safety 59: 73-7. 
Témoignages (2005-06) All articles containing the search term "Chikungunya", 2005 and 2006, http://www.temoignages.re/, accessed November 2006.

Vaxelaire, D. (2002) Portraits d'une île, Ste-Marie (Réunion): Azalées Éditions.

Vergès, F. (2003) The Island of Wandering Souls, in R. Edmond \& V. Smith (eds.) Islands in History and Representation, London: Routlege Research in Postcolonial Literatures.

Watin, M. (in press) «Polémique, rumeur et tension: Aspects de la «crise» du chikungunya dans l'espace publique médiatique réunionnais », in Chronique d'une crise sanitaire, économique et sociale: L'île de La Réunion face au Chikungunya, Paris: UMR Prodig, Infogéo.

Weinstein, P. \& Ravi, S. (2008) "The failure of colonial 'distancing': changing representations of the 2005-6 Chikungunya virus epidemic in Réunion", Singapore Journal of Tropical Geography 29: 221-35.

WHO (World Health Organization) (2000) Consensus meeting on surveillance of infectious diseases: Report on a WHO meeting, Grottaferrata, Italy 4-7 April 2000, Regional Office for Europe: World Health Organization.

WHO (World Health Organization) (2002) Se préparer pour faire face à l'usage délibéré d'agents biologiques: Pour une approche rationelle face à l'impensable, Geneva: World Health Organization. 